Jurnal Mahasiswa BK An-Nur : Berbeda, Bermakna, Mulia

Volume 7 Nomor 3 Tahun 2021

Tersedia Online: https://ojs.uniska-bjm.ac.id/index.php/AN-NUR

p-ISSN. 2460-9722 | e-ISSN. 2622-8297

\title{
ORIENTASI KARIR PADA GURU MADRASAH ALIYAH UNGGULAN DI INDONESIA \\ (Studi Deskriptif Berdasarkan Teori Jangkar Karir Schein)
}

\author{
Khaeriah $^{1}$, Dede Rahmat Hidayat ${ }^{2}$, Herdi ${ }^{3}$ \\ ${ }^{123}$ Fakultas Ilmu Pendidikan, Universitas Negeri Jakarta, \\ E-mail: khaeriah_1108817008@mhs.unj.ac.id /08998611992
}

\begin{abstract}
ABSTRAK
Abstrak: Orientasi karir pada guru menjadi hal yang menarik untuk dikaji, karena guru menjadi salah satu pekerjaan yang banyak didambakan oleh banyak orang juga memiliki prosepek masa depan. Penelitian ini bertujuan untuk mengekspolorasi orientasi karir pada guru berdasarkan latar belakang gender, jenjang pendidikan dan asal daerah (letak geografis). Schein merujuk orientasi karir seseorang pada 9 dimensi jangkar karir. Sampel penelitian yaitu guru-guru dari sembilan MAN IC yang terdiri dari 157 responden. Pemilihan populasi dan sampel menggunakan teknik area sampling. Hasil penelitian menunjukkan bahwa pertama gambaran umum orientasi karir pada guru man ic yang paling tinggi rata-ratanya yaitu pada dimensi keamanan kerja. Kedua, dari 9 jangkar karir, 8 dimensi tidak terdapat perbedaan orientasi karir pada guru laki-laki maupun perempuan, kecuali pada dimensi kompetensi manajerial. Ketiga tidak terdapat perbedaan orientasi karir pada guru berdasarkan jenjang pendidikan, baik dari S1, S2 maupun S3. Keempat, dari 9 jangkar karir, 7 dimensi jangkar karir tidak terdapat perbedaan orientasi karir guru berdasarkan asal daerah (letak geografis), kecuali pada dimensi kompetensi manajerial dan keamanan kerja.
\end{abstract}

Kata Kunci: Orientasi karir, Guru, Jangkar karir

\begin{abstract}
Career orientation for teachers is an interesting thing to study, because teachers are one of the jobs that many people covet and also have future prospects. This study aims to explore the career orientation of teachers based on gender background, education level and regional origin (geographical location). Schein refers to a person's career orientation on 9 dimensions of career anchors. The research sample is teachers from nine MAN IC consisting of 157 respondents. Population and sample selection using area sampling technique. The results of the study show that the first general description of career orientation in MAN IC teachers is the highest average, namely the dimension of job security. Second, from 9 career anchors, 8 dimensions have no differences in career orientation for male and female teachers, except for the managerial competence dimension. Third, there is no difference in the career orientation of teachers based on education level, both from S1, S2 and S3. Fourth, from 9 career anchors, 7 career anchor dimensions, there is no difference in teacher career orientation based on regional origin (geographical location), except for the dimensions of managerial competence and job security.
\end{abstract}

Keywords: Career orientation, Teacher, Career anchor

Dipublikasikan Oleh :

UPT Publikasi dan Pengelolaan Jurnal

Universitas Islam Kalimantan Muhammad Arsyad Al-Banjari Banjarmasin 


\section{Khaeriah $^{1}$, Dede Rahmat Hidayat ${ }^{2}$, Herdi $^{3}$ \\ Jurnal Mahasiswa BK An-Nur : Berbeda, Bermakna, Mulia \\ Volume 7 Nomer 3 Tahun 2021 \\ Tersedia Online: https://ojs.uniska-bjm.ac.id/index.php/AN-NUR \\ p-ISSN. 2460-9722 | e-ISSN. 2622-8297}

\section{PENDAHULUAN}

Guru memiliki peran yang penting dalam meningkatkan kualitas pendidikan nasional. Saat ini guru bukan hanya sekedar memberikan informasi ilmu pengetahuan dan teknologi saja, tapi juga bagaimana ia membentuk sikap dan jiwanya sehingga mampu bertahan dalam era hiperkompetisi (Mustofa, 2012). Namun berdasarkan data UNESCO tahun 2016 menyebutkan bahwa guru di Indonesia berada pada posisi ke-14 dari 14 negara berkembang, salah satu faktor penyebabnya yaitu cara pandang guru tentang profesinya yang masih kurang tepat (Utami, 2019). Lembaga harus menyadari bahwa perlu ada penyesuaian antara nilai-nilai pegawai dan lingkungan kerja karena merupakan indikator yang relevan untuk mencapai kepuasan kerja (Vargas \& Teixeira, 2018).

Saat ini penghasilan bukan menjadi komponen utama indikator kesuksesan, tapi kebahagiaan dan kepuasan kerja juga tak kalah penting. Orientasi karir dapat mempengaruhi kebahagiaan hidup dan kepuasan kerja seseorang (Coetzee et al., 2010). Shockley (Akmal \& Arlinkasari, 2017) menyebutkan bahwa indikator untuk mengukur kesuksesan karir seseorang itu ada 2 yaitu; kesuksesan karir secara obyektif dan kesuksesan karir secara subjektif. Dimana kesuksesan karir objektif mengacu pada jumlah pendapatan dan promosi pada suatu pekerjaan, sedangkan kesuksesan karir subjektif mengacu pada perasaan seseorang terhadap karirnya.

Usaha untuk meraih posisi karir akan berkaitan dengan pembangunan orientasi karir (Saputri \& Yusuf, 2016). Secara harfiah, kata oriented sendiri bermakna terah, tertuju atau terfokus. Sedangkan kata "karir" merujuk pada seperangkat pengalaman kerja dan peran yang membentuk kehidupan karir (Schein, 1990). Orientasi karir merupakan keseluruhan konsep diri karir yang terdiri dari fokus sikap dan nilai, bakat dan kemampuan, motif serta kebutuhan yang berkaitan dengan karir seseorang (Bravo et al., 2017). Selain itu Derr (Yurike, 2014) menyebutkan bahwa orientasi karir sebagai sebuah pemahaman terhadap gambaran seseorang untuk melakukan pilihan karir.

Elemen penting dari karir terdiri dari 2 yaitu karir internal dan karir eksternal (Igbaria \& Baroudi, 1993). Karir internal mengacu pada kebutuhan, nilai dan bakat yang dipersepsikan individu dalam keputusan karirnya. Sedangkan karir eksternal berkaitan dengan organisasi atau perusahaan.

Schein mengistilahkan jangkar karir untuk merujuk pada orientasi karir seseorang yang berpengaruh pada pilihan karirnya (Igbaria \& Baroudi, 1993). Berdasarkan pendefinisian orientasi karir tersebut maka peneliti menyimpulkan bahwa orientasi karir merupakan nilai-nilai, cara pandang, kebutuhan seseorang terhadap bagaimana ia menentukan sikap atau mengambil keputusan untuk mencapai kesuksesan karir.

Orientasi karir pada guru sangat menarik untuk dibahas, selain karena guru sering dipandang sebagai sosok yang memiliki kepribadian ideal dan panutan (Mundiri \& Bariroh, 2019), tidak bisa kita pungkiri juga bahwa profesi guru sangat menjanjikan, memiliki prospek masa depan dan didambakan banyak orang. Memiliki orientasi karir akan membantu guru untuk mengembangkan karirnya, dengan pengembangan karirnya akan meningkatkan loyalitas guru terhadap pekerjaannya (Asnita Putri Dewi, 2020).

Menurut Jigmi Dorji (Chandra, 2017) orientasi karir seseorang dipengaruhi oleh beberapa faktor, seperti gender, status ekonomi, usia, kebijakan dan lingkungan.

Schein (Igbaria et al., 1991) menemukan bahwa gender mempengaruhi orientasi karir seseorang. Tilaar dan Riant Nugroho (Disas, 2017) memandang latar belakang pendidikan mempengaruhi kualitas guru, bila kualitas guru baik, maka kualitas pendidikan dianggap akan meningkat. Selain itu latar belakang daerah juga berpengaruh pada pembentukan orientasi karir seseorang baik karena faktor budaya maupun geografis. Sudah bukan rahasia umum lagi bahwa saat ini masih terjadi kesenjangan antara daerah perkotaan dengan pedesaan dalam hal pendidikan (Vito \& Krisnani, 2015), baik karena kurang meratanya pembangunan nasional maupun sumber daya guru tersebut. Budaya mempengaruhi bagaimana konsep dan pola berfikir individu sehingga mempengaruhi orientasi karirnya. Hal ini senada dengan penelitian Widodo et al. (2020) yang menyatakan bahwa budaya, situasi lingkungan kerja dan kehidupan pola masyarakat setempat mempengaruhi jangkar karir individu.

MAN IC sebagai salah satu madrasah unggulan yang berada dibawah naungan Kementerian Agama Republik Indonesia memiliki sumber daya guru sebagai tenaga pendidik serta peserta didik yang unggul berprestasi. Hal ini karena proses seleksi guru maupun peserta didiknya dilakukan secara ketat dan pilihan. Berdasarkan analisa lapangan, guru-guru MAN IC sangat loyal terhadap lembaga, mereka sangat berupaya menyumbangkan gagasan, waktu dan tenaganya untuk kemajuan peserta didik maupun lembaga. Namun mereka juga tetap aktif mengembangkan dirinya. Guru-guru di MAN IC ini juga cenderung menetap lama atau jarang terjadi

Dipublikasikan Oleh :

UPT Publikasi dan Pengelolaan Jurnal

Universitas Islam Kalimantan Muhammad Arsyad Al-Banjari Banjarmasin 


\section{Khaeriah $^{1}$, Dede Rahmat Hidayat ${ }^{2}$, Herdi $^{3}$ \\ Jurnal Mahasiswa BK An-Nur : Berbeda, Bermakna, Mulia \\ Volume 7 Nomer 3 Tahun 2021 \\ Tersedia Online: https://ojs.uniska-bjm.ac.id/index.php/AN-NUR \\ p-ISSN. 2460-9722 | e-ISSN. 2622-8297}

mutasi walaupun guru-gurunya berasal dari daerah yang jauh dari lokasi MAN IC sendiri. Namun karena memiliki asrama atau rumah dinas guru, sehingga guru-guru yang berasal dari daerah luar bisa menetap di dalam Madrasah.

Berdasarkan latar belakang yang telah diuraikan, maka penulis tertarik untuk mengkaji bagaimana orientasi karir pada guru MAN IC berdasarkan latar belakang gender, jenjang pendidikan dan asal daerah (letak geografis) dengan melihat kecenderungan jangkar karir mana yang lebih dominan.

Schein (Susanti, 2014) menjelaskan bahwa jangkar karir merupakan pola bakat, motif dan nilai yang dirasakan sendiri berfungsi untuk membimbing, membatasi, menstabilkan, dan mengintegrasikan karir. Igbaria \& Baroudi (1993) mendefinisikan jangkar karir sebagai persepsi individu terhadap kebutuhan, nilai-nilai, dan bakat yang membentuk keputusan karirnya.

Jangkar karir membentuk konsep karir diri seseorang sehingga memberikan kecenderungan nilai dan motif yang kuat dalam pengambilan keputusan karir. Awalnya Schein berasumsi bahwa pada diri individu hanya memiliki satu jangkar karir dominan, cenderung menetap dan tidak berubah. Namun hal tersebut berbeda dengan pendapat Feldman dan Balino (Bravo et al., 2017) yang menyatakan bahwa seseorang memiliki bebarapa jangkar karir dan jangkar karir tersebut dapat berubah dari waktu ke waktu sebagai suatu akibat dari pengalaman dan tantangan baru. Selain itu 10 dari 44 panelis peneliti juga menemukan bahwa individu memiliki memiliki dua atau tiga jangkar karir dominan (Rodrigues et al., 2013).

Menurut Schein (Leong et al., 2014), jangkar karir akan membantu seseorang untuk memperjelas peferensi (kecenderungan) karir sehingga akan membantu dalam membuat pilihan dan keputusan karir yang lebih bijaksana. Hal ini menunjukkan bahwa dengan mengetahui jangkar karir diri maka akan memberikan arahan atau pandangan terhadap motif, kebutuhan atau nilai-nilai pada dimensi jangkar karir mana yang paling dominan dalam diri kita sehingga kita akan memutuskan pilihan karir dengan tepat, bijaksana dan bertanggungjawab bahkan kita akan terus mempertahankannya meskipun kita menemukan kondisi dimana karir yang kita pertahankan tersebut tidak memuaskan (Widodo et al., 2020).

Schein membagi jangkar karir seseorang ke dalam 8 dimensi, kemudian pada tahun 1992 Igbaria dan Barodi kemudian mengambangkan menjadi 9 dimensi, diantaranya yaitu pertama kompetensi teknik (technical competence) yaitu terkait nilai dan bakat seseorang pada orientasi teknis yang kuat, berfokus pada hal-hal intrinsik (keahlilan, keterampilan, pendidikan dan pengalaman kerja). Kedua, kompetensi managerial yaitu terkait nilai, motif dan kebutuhan seseorang pada hal-hal manajerial untuk mengawasi, mempengaruhi, dan mempengaruhi orang lain serta keingingan untuk mencapai jabatan tertinggi. Ketiga otonomi (autonomi), yaitu nilai, motif dan kebutuhan seseorang terkait kebebasan dalam bekerja, mereka tidak suka aturan organisasi yagn mengekang. Keempat, kemanan geografis yaitu berkaitan dengan kebutuhan akan rasa aman yang kaitannya dengan wilayan geografis tertentu dan dalam jangka panjang. Kelima, kemananan kerja (stabilitas kerja) yaitu nilai, motif dan kebutuhan rasa aman terhadap loyalitas lembaga/organisasi, keamanan finansial dan jenjang karir jangka panjang. Keenam, kreativitas dan kewirausahaan yaitu nilai, motif dan kebutuhan untuk menciptakan suatu usaha atau bisnis baru melalui manipulasi keuangan. Ketujuh, rasa pelayanan yaitu nilai, motif dan kebutuhan untuk melayani orang lain dan membuat dunia menjadi tempat tinggal dan bekerja yang lebih baik. Kedelapan, tantangan murni yaitu nilai, motif dan kebutuhan untuk memecahkan permasalahan yang sangat sulit, mengatasi rintangan dan hambatan, serta memenangkan persaingan meskipun menghadapi lawan yang tanggun. Kesembilan, integrasi gaya hidup yaitu nilai, motif dan kebutuhan untuk mengembangkan gaya hidup yang dintegrasikan dengan keluarga dan karir dengan kepedulian untuk pengembangan diri.

Feldman dan Balino (Coetzee et al., 2010) membagi sembilan jangkar karir menjadi tiga kelompok yang berbeda sesuai dengan motivasinya yaitu pertama jangkar berbasis kebutuhan (needbased anchor) ang terdiri dari dimensi jangkar karir keamanan kerja (stabilitas dan geografis), integrasi gaya hidup. Kedua jangkar berbasis nilai (value-based anchors) terdiri dari jangkar karir tantangan murni, rasa pelayanan. Ketiga, jangkar terkait bakat (talentsbased anchors) terdiri dari kompetensi manajerial, kompetensi teknik,

\section{METODE}

Penelitian ini merupakan studi deskriptif komparatif yang digunakan untuk memperoleh gambaran orientasi karir pada guru di MAN IC berdasarkan latar belakang gender, jenjang pendidikan

Dipublikasikan Oleh :

UPT Publikasi dan Pengelolaan Jurnal

Universitas Islam Kalimantan Muhammad Arsyad Al-Banjari Banjarmasin 
Khaeriah $^{1}$, Dede Rahmat Hidayat ${ }^{2}$, Herdi $^{3}$

Jurnal Mahasiswa BK An-Nur : Berbeda, Bermakna, Mulia

Volume 7 Nomer 3 Tahun 2021

Tersedia Online: https://ojs.uniska-bjm.ac.id/index.php/AN-NUR

p-ISSN. 2460-9722 | e-ISSN. 2622-8297

dan letak geografis. Pengumpulan data menggunakan metode survey.

Populasi sampel penelitian ini adalah guru MAN IC. Sampel dipilih dengan teknik cluster sampling. Dari 23 MAN IC di seluruh Indonesia, dipilih 9 MAN IC berdasarkan pertimbangan perwakilan letak geografis wilayah kepulauan di Indonesia. Dari 9 MAN IC tersebut didapatkan total guru sebanyak 327 orang guru, namun yang lengkap mengisi angket penelitian yaitu sebanyak 157 responden. Dari 157 responden terdiri dari 79 lakilaki, 78 perempuan, yang memiliki jenjang S1 sebanyak 86 orang, S2 sebanyak 67 orang dan S3 sebanyak 4 orang, sedangkan dari wilayan Jawa sebanyak 53 orang, Sulawesi 33 orang, Sumatera 19 orang, Kalimantan 49 orang dan Papua sebanyak 3 orang.

Instrumen penelitian menggunakan Career Orientation Inventory (COI) yang dikembangkan oleh Igbaria dan Baroudi (1993) yaitu terdiri dari 25 item pernyataan dengan skala Likert 5 pilihan, no 1-15 ditunjukkan dalam 5 skala dari sangat tidak penting hingga sangat penting. Dan no 16-25 menggunakan 5 skala dari sangat tidak sesuai hingga sangat sesuai. Sebelum digunakan, instrumen dilakukan proses adaptasi terlebih dahulu kedalam bahasa Indonesia dan dilakukan uji ahli Bahasa dan Psikologi Karir.

Pengujian validitas menggunakan korelasi product moment dan uji reliabilitas menggunakan metode cronbach alpha. Teknik analisis untuk menguji hipotesis penelitian menggunakan analysis of variance (ANOVA) dan uji t-test. Adapun hipotesis penelitian ini adalah sebagai berikut (1)

Uji t-test digunakan untuk menguji perbedaan orientasi karir pada guru berdasarkan gender (laki-laki dan perempuan). Sedangkan ANOVA untuk menguji perbedaan berdasarkan jenjang pendidikan yang dibagi kedalam tiga variabel yaitu $\mathrm{S} 1, \mathrm{~S} 2$ dan $\mathrm{S} 3$. Serta untuk menguji perbedaan orientasi karir pada guru berdasarkan asal daerah (letak geografis) yang dibagi kedalam lima variabel yaitu Jawa, Sumatera, Sulawesi, Kalimantan dan Papua.

\section{HASIL DAN PEMBAHASAN \\ Hasil}

Orientasi Karir Pada Guru Berdasarkan Latar Belakang Gender

Tabel 1

Hasil Uji Perbedaan Orientasi Karir Guru Berdasarkan Latar Belakang Gender

\begin{tabular}{|c|c|c|c|c|c|c|}
\hline & $\mathrm{N}$ & Mean & $\begin{array}{c}\text { Perbedaan } \\
\text { mean }\end{array}$ & $\mathrm{F}$ & $\begin{array}{l}\text { Sig (2- } \\
\text { tailed) }\end{array}$ & $\begin{array}{c}\text { Inter- } \\
\text { pretasi }\end{array}$ \\
\hline \multicolumn{7}{|c|}{ Kompetensi Teknis } \\
\hline $\mathrm{L}$ & 79 & 4.055 & \multirow{2}{*}{-0.189} & \multirow{2}{*}{4.851} & \multirow{2}{*}{0.074} & \multirow{2}{*}{$\begin{array}{c}\text { Tidak } \\
\text { berbeda }\end{array}$} \\
\hline $\mathrm{P}$ & 78 & 4.244 & & & & \\
\hline \multicolumn{7}{|c|}{ Kompetensi Manajerial } \\
\hline $\mathrm{L}$ & 79 & 4.008 & \multirow{2}{*}{0.196} & \multirow{2}{*}{0.011} & \multirow{2}{*}{0.046} & \multirow[t]{2}{*}{ Berbeda } \\
\hline $\mathrm{P}$ & 78 & 3.812 & & & & \\
\hline \multicolumn{2}{|c|}{ Otonomi } & & & & & \\
\hline $\mathrm{L}$ & 79 & 3.772 & \multirow{2}{*}{0.204} & \multirow{2}{*}{0.084} & \multirow{2}{*}{0.132} & \multirow{2}{*}{$\begin{array}{c}\text { Tidak } \\
\text { berbeda }\end{array}$} \\
\hline $\mathrm{P}$ & 78 & 3.568 & & & & \\
\hline \multicolumn{2}{|c|}{ Keamanan Kerja } & & & & & \\
\hline $\mathrm{L}$ & 79 & 4.538 & \multirow{2}{*}{0.006} & \multirow{2}{*}{0.164} & \multirow{2}{*}{0.95} & \multirow{2}{*}{$\begin{array}{c}\text { Tidak } \\
\text { berbeda }\end{array}$} \\
\hline $\mathrm{P}$ & 78 & 4.532 & & & & \\
\hline \multicolumn{2}{|c|}{ Keamanan Geografis } & & & & & \\
\hline $\mathrm{L}$ & 79 & 3.69 & \multirow{2}{*}{-0.073} & \multirow{2}{*}{2.523} & \multirow{2}{*}{0.641} & \multirow{2}{*}{$\begin{array}{c}\text { Tidak } \\
\text { berbeda }\end{array}$} \\
\hline $\mathrm{P}$ & 78 & 3.763 & & & & \\
\hline \multicolumn{2}{|c|}{ Kreativitas dan } & & & & & \\
\hline
\end{tabular}

\section{Dipublikasikan Oleh :}

UPT Publikasi dan Pengelolaan Jurnal

Universitas Islam Kalimantan Muhammad Arsyad Al-Banjari Banjarmasin 
Khaeriah $^{1}$, Dede Rahmat Hidayat ${ }^{2}$, Herdi $^{3}$ Jurnal Mahasiswa BK An-Nur : Berbeda, Bermakna, Mulia Volume 7 Nomer 3 Tahun 2021

Tersedia Online: https://ojs.uniska-bjm.ac.id/index.php/AN-NUR p-ISSN. 2460-9722 | e-ISSN. 2622-8297

\begin{tabular}{|c|c|c|c|c|c|c|}
\hline \multicolumn{2}{|c|}{ Kewirausahaan } & & & \multirow{3}{*}{0.148} & \multirow{3}{*}{0.355} & \multirow{3}{*}{$\begin{array}{c}\text { Tidak } \\
\text { berbeda }\end{array}$} \\
\hline $\mathrm{L}$ & 79 & 3.7 & \multirow{2}{*}{0.136} & & & \\
\hline P & 78 & 3.564 & & & & \\
\hline \multicolumn{2}{|c|}{ Rasa Pelayanan } & & & & & \\
\hline $\mathrm{L}$ & 79 & 4.194 & \multirow{2}{*}{0.002} & \multirow{2}{*}{0.037} & \multirow{2}{*}{0.986} & \multirow{2}{*}{$\begin{array}{c}\text { Tidak } \\
\text { berbeda }\end{array}$} \\
\hline $\mathrm{P}$ & 78 & 4.192 & & & & \\
\hline \multicolumn{2}{|c|}{ Tantangan Murni } & & & & & \\
\hline $\mathrm{L}$ & 79 & 4.194 & \multirow{2}{*}{0.027} & \multirow{2}{*}{0.282} & \multirow{2}{*}{0.793} & \multirow{2}{*}{$\begin{array}{c}\text { Tidak } \\
\text { berbeda }\end{array}$} \\
\hline $\mathrm{P}$ & 78 & 4.167 & & & & \\
\hline \multicolumn{2}{|c|}{ Integrasi Gaya Hidup } & & \multirow{3}{*}{0.245} & & \multirow{3}{*}{0.053} & \multirow{3}{*}{$\begin{array}{c}\text { Tidak } \\
\text { berbeda }\end{array}$} \\
\hline $\mathrm{L}$ & 79 & 3.506 & & \multirow{2}{*}{0.476} & & \\
\hline $\mathrm{P}$ & 78 & 3.261 & & & & \\
\hline
\end{tabular}

Berdasarkan hasil uji t-test menunjukkan hasil bahwa dari sembilan dimensi orientasi karir pada guru, terdapat satu dimensi yang memiliki nilai $p<$ 0.05 yaitu pada dimensi kompetensi manajerial. Hal ini berarti bahwa dari sembilan dimensi jangkar karir, delapan dimensi tidak terdapat perbedaan signifikan orientasi karir pada guru MAN IC baik laki-laki maupun perempuan yaitu dalam dimensi kompetensi teknis, otonomi, keamanan kerja, keamanan geografis, kreatifitas dan kewirausahaan, rasa pelayanan, tantangan murni dan integrasi gaya hidup. Namun terdapat perbedaan orientasi karir pada guru MAN IC pada dimensi kompetensi manajerial dimana skor guru laki-laki lebih tinggi dari skor guru perempuan.

\section{Orientasi Karir Pada Guru Berdasarkan Jenjang Pendidikan}

Tabel 2

Hasil Uji Perbedaan Orientasi Karir Pada Guru Berdasarkan Jenjang Pendidikan

\begin{tabular}{|c|c|c|c|c|c|}
\hline & $\mathrm{N}$ & Mean & $\mathrm{F}$ & $\begin{array}{l}\text { Sig (2- } \\
\text { tailed) }\end{array}$ & Interpretasi \\
\hline \multicolumn{6}{|c|}{ Kompetensi Teknis } \\
\hline $\mathrm{S} 1$ & 86 & 4.213 & \multirow{3}{*}{1.019} & \multirow{3}{*}{0.363} & \multirow{3}{*}{$\begin{array}{c}\text { Tidak } \\
\text { berbeda }\end{array}$} \\
\hline $\mathrm{S} 2$ & 67 & 4.08 & & & \\
\hline S3 & 4 & 3.917 & & & \\
\hline \multicolumn{6}{|c|}{ Kompetensi Manajerial } \\
\hline $\mathrm{S} 1$ & 86 & 3.915 & \multirow{3}{*}{0.177} & \multirow{3}{*}{0.838} & \multirow{3}{*}{$\begin{array}{c}\text { Tidak } \\
\text { berbeda }\end{array}$} \\
\hline $\mathrm{S} 2$ & 67 & 3.895 & & & \\
\hline $\mathrm{S} 3$ & 4 & 4.083 & & & \\
\hline \multicolumn{2}{|c|}{ Otonomi } & & & & \\
\hline $\mathrm{S} 1$ & 86 & 3.659 & \multirow{3}{*}{0.02} & \multirow{3}{*}{0.98} & \multirow{3}{*}{$\begin{array}{c}\text { Tidak } \\
\text { berbeda }\end{array}$} \\
\hline $\mathrm{S} 2$ & 67 & 3.687 & & & \\
\hline S3 & 4 & 3.666 & & & \\
\hline \multicolumn{2}{|c|}{ Keamanan Kerja } & & & & \\
\hline $\mathrm{S} 1$ & 86 & 4.546 & \multirow{2}{*}{0.162} & \multirow{2}{*}{0.851} & \multirow{2}{*}{$\begin{array}{c}\text { Tidak } \\
\text { berbeda }\end{array}$} \\
\hline $\mathrm{S} 2$ & 67 & 4.530 & & & \\
\hline
\end{tabular}

\section{Dipublikasikan Oleh :}

UPT Publikasi dan Pengelolaan Jurnal

Universitas Islam Kalimantan Muhammad Arsyad Al-Banjari Banjarmasin 
Khaeriah $^{1}$, Dede Rahmat Hidayat ${ }^{2}$, Herdi $^{3}$ Jurnal Mahasiswa BK An-Nur : Berbeda, Bermakna, Mulia

Volume 7 Nomer 3 Tahun 2021

Tersedia Online: https://ojs.uniska-bjm.ac.id/index.php/AN-NUR

p-ISSN. 2460-9722 | e-ISSN. 2622-8297

\begin{tabular}{|c|c|c|c|c|c|}
\hline S3 & 4 & 4.375 & & & \\
\hline \multicolumn{2}{|c|}{ Keamanan Geografis } & & & & \multirow{4}{*}{$\begin{array}{c}\text { Tidak } \\
\text { berbeda }\end{array}$} \\
\hline S1 & 86 & 3.756 & \multirow{3}{*}{0.598} & \multirow{3}{*}{0.551} & \\
\hline $\mathrm{S} 2$ & 67 & 3.716 & & & \\
\hline S3 & 4 & 3.25 & & & \\
\hline \multicolumn{2}{|c|}{$\begin{array}{l}\text { Kreativitas dan } \\
\text { Kewirausahaan }\end{array}$} & & & & \\
\hline $\mathrm{S} 1$ & 86 & 3.666 & \multirow{3}{*}{0.517} & \multirow{3}{*}{0.597} & \multirow{3}{*}{$\begin{array}{c}\text { Tidak } \\
\text { berbeda }\end{array}$} \\
\hline $\mathrm{S} 2$ & 67 & 3.597 & & & \\
\hline S3 & 4 & 3.5 & & & \\
\hline \multicolumn{2}{|c|}{ Rasa Pelayanan } & & & & \multirow{4}{*}{$\begin{array}{c}\text { Tidak } \\
\text { berbeda }\end{array}$} \\
\hline S1 & 86 & 4.232 & \multirow{3}{*}{0.366} & \multirow{3}{*}{0.694} & \\
\hline $\mathrm{S} 2$ & 67 & 4.144 & & & \\
\hline S3 & 4 & 4.166 & & & \\
\hline \multicolumn{2}{|c|}{ Tantangan Murni } & & & & \multirow{4}{*}{$\begin{array}{c}\text { Tidak } \\
\text { berbeda }\end{array}$} \\
\hline S1 & 86 & 4.221 & \multirow{3}{*}{0.597} & \multirow{3}{*}{0.552} & \\
\hline $\mathrm{S} 2$ & 67 & 4.144 & & & \\
\hline S3 & 4 & 3.917 & & & \\
\hline \multicolumn{2}{|c|}{ Integrasi Gaya Hidup } & & & & \multirow{4}{*}{$\begin{array}{c}\text { Tidak } \\
\text { berbeda }\end{array}$} \\
\hline $\mathrm{S} 1$ & 86 & 3.395 & \multirow{3}{*}{0.073} & \multirow{3}{*}{0.929} & \\
\hline $\mathrm{S} 2$ & 67 & 3.363 & & & \\
\hline S3 & 4 & 3.5 & & & \\
\hline
\end{tabular}

Berdasarkan hasil uji ANOVA terhadap variabel jenjang pendidikan menunjukkan bahwa dari sembilan dimensi jangkar karir memiliki nilai $p>0.05$ yang artinya tidak terdapat perbedaan secara signifikan orientasi karir pada guru MAN IC terhadap jenjang pendidikan baik S1, S2 maupun S3.

Orientasi Karir Pada Guru Berdasarka Asal Daerah (Letak Geografis)

Tabel 3

Hasil Uji Perbedaan Orientasi Karir Pada Guru Berdasarkan Asal Daerah (Letak Geografis)

\begin{tabular}{|c|c|c|c|c|c|}
\hline & $\mathrm{N}$ & Mean & $\mathrm{F}$ & $\begin{array}{l}\text { Sig (2- } \\
\text { tailed) }\end{array}$ & Interpretasi \\
\hline \multicolumn{6}{|c|}{ Kompetensi Teknis } \\
\hline Jawa & 53 & 4.082 & \multirow{5}{*}{0.808} & \multirow{5}{*}{0.522} & \multirow{5}{*}{$\begin{array}{c}\text { Tidak } \\
\text { berbeda }\end{array}$} \\
\hline Sumatera & 19 & 4.14 & & & \\
\hline Sulawesi & 33 & 4.061 & & & \\
\hline Kalimantan & 49 & 4.265 & & & \\
\hline Papua & 3 & 4.444 & & & \\
\hline \multicolumn{2}{|c|}{ Kompetensi Manajerial } & & & & \\
\hline Jawa & 53 & 3.717 & \multirow{3}{*}{2.767} & \multirow{3}{*}{0.03} & \multirow[t]{3}{*}{ Berbeda } \\
\hline Sumatera & 19 & 4.105 & & & \\
\hline Sulawesi & 33 & 4.111 & & & \\
\hline
\end{tabular}

\section{Dipublikasikan Oleh :}

UPT Publikasi dan Pengelolaan Jurnal

Universitas Islam Kalimantan Muhammad Arsyad Al-Banjari Banjarmasin 
Khaeriah $^{1}$, Dede Rahmat Hidayat ${ }^{2}$, Herdi $^{3}$ Jurnal Mahasiswa BK An-Nur : Berbeda, Bermakna, Mulia

Volume 7 Nomer 3 Tahun 2021

Tersedia Online: https://ojs.uniska-bjm.ac.id/index.php/AN-NUR

p-ISSN. 2460-9722 | e-ISSN. 2622-8297

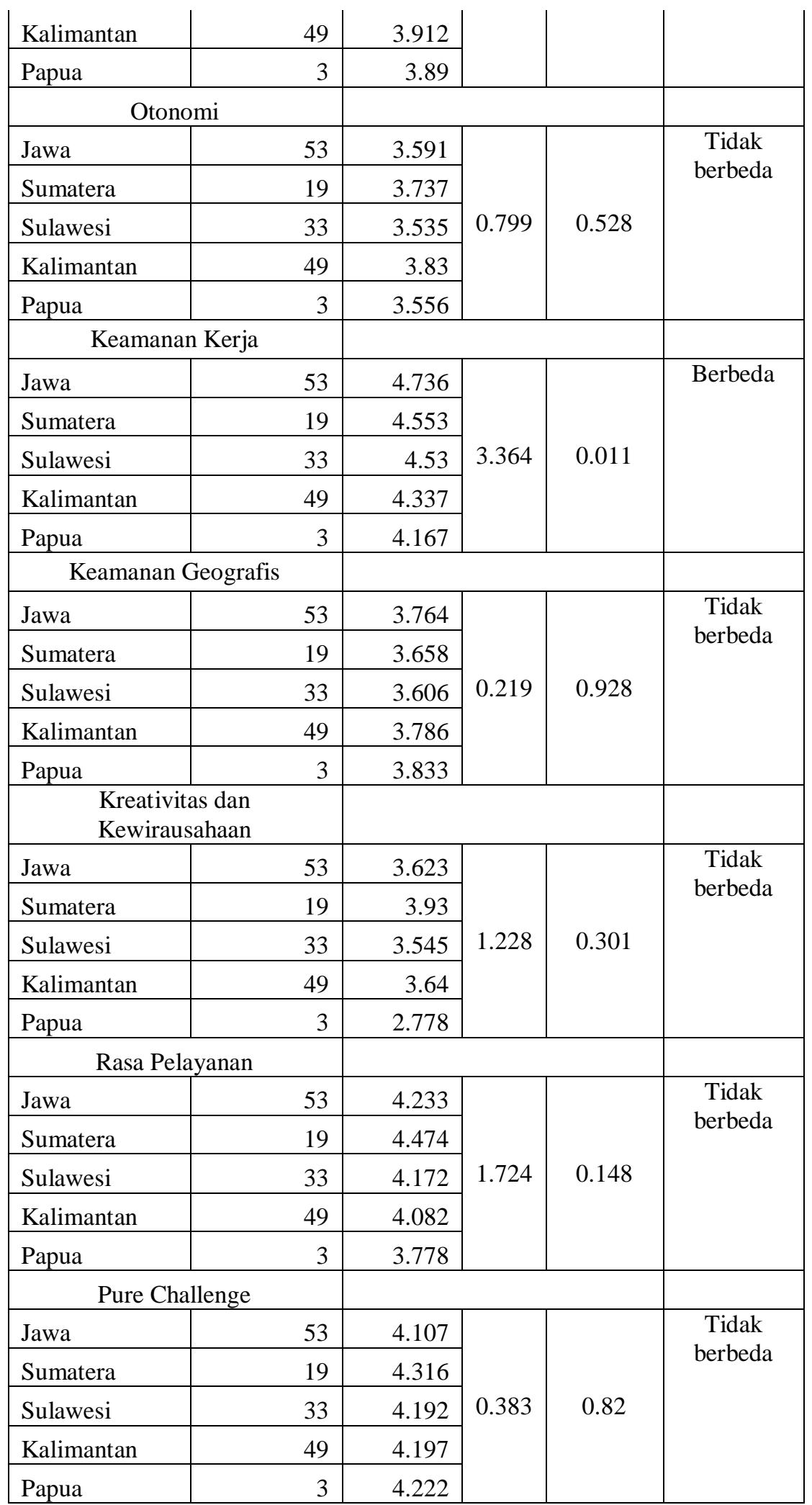

\section{Dipublikasikan Oleh :}

UPT Publikasi dan Pengelolaan Jurnal

Universitas Islam Kalimantan Muhammad Arsyad Al-Banjari Banjarmasin 


\section{Khaeriah $^{1}$, Dede Rahmat Hidayat ${ }^{2}$, Herdi $^{3}$ \\ Jurnal Mahasiswa BK An-Nur : Berbeda, Bermakna, Mulia \\ Volume 7 Nomer 3 Tahun 2021 \\ Tersedia Online: https://ojs.uniska-bjm.ac.id/index.php/AN-NUR \\ p-ISSN. 2460-9722 | e-ISSN. 2622-8297}

\begin{tabular}{|c|c|c|c|c|c|}
\hline \multicolumn{2}{|c|}{ Integrasi Gaya Hidup } & & \multirow{6}{*}{0.988} & \multirow{6}{*}{0.416} & \multirow{6}{*}{$\begin{array}{l}\text { Tidak } \\
\text { berbeda }\end{array}$} \\
\hline Jawa & 53 & 3.365 & & & \\
\hline Sumatera & 19 & 3.368 & & & \\
\hline Sulawesi & 33 & 3.192 & & & \\
\hline Kalimantan & 49 & 3.544 & & & \\
\hline Papua & 3 & 3.333 & & & \\
\hline
\end{tabular}

Berdasarkan hasil uji ANOVA terhadap variabel asal daerah (letak geografis) menunjukkan bahwa dari sembilan dimensi jangkar karir, terdapat dua dimensi dengan nilai $p<0.05$ yaitu pada dimensi kompetensi manajerial dan keamanan kerja. Hal ini berarti bahwa tujuh dimensi jangkar karir tidak terdapat perbedaan signifikan orientasi karir pada guru terhadap asal daerah (baik yang berasal dari Jawa, Sumatera, Sulawesi, Kalimantan dan Papua) yaitu pada dimensi jangkar karir kompetensi teknis, otonomi, keamanan geografis, kreativitas dan kewirausahaan, rasa pelayanan, tantangan murni dan integrasi gaya hidup. Namun terdapat perbedaan orientasi karir guru berdasarkan asal daerah yaitu pada dimensi kompetensi manajerial dan kemanan kerja.

Secara berurutan perbedaan dimensi kompetensi manajerial ini ditunjukkan dari skor tertinggi yaitu guru yang berasal dari Sulawesi, Smatera, Kalimantan, Papua dan Jawa. Sedangkan perbedaan pada dimensi keamanan kerja, ditunjukkan dari skor tertinggi yaitu guru yang berasal dari Jawa, Sumatera, Sulawesi, Kalimantan dan Papua.

\section{Pembahasan}

Profesi guru memerlukan kajian akademik dan vokasi (Yuksel-Sahin \& Hotaman, 2009) karena guru harus memiliki pandangan yang rinci tentang diri dan profesinya. Bahkan kesukses guru dapat berpengaruh pada kesuksesan peserta didiknya (Trisnowati, 2016). Secara umum karir guru terbagi menjadi dua (Mukti, 2017), pertama yaitu karir struktural yaitu yang berkaitan dengan kedudukan seseraong dalam struktur organisasi tempat ia bekerja. Kedua yaitu karir fungsional yaitu yang berkaitan dengan tingkatan atau pencapaian formal seseorang dalam profesi yang ia jalani.

\section{Orientasi Karir Guru Berdasarkan Gender}

Kanter (Yurike, 2014) menjelaskan bahwa perempuan lebih banyak mengalami hambatan dalam mencapai karirnya dibanding dengan laki-laki, hal ini terkait dengan stigma budaya yang membuat perempuan kurang bebas untuk menentukan karirnya. Penelitian terhadap 297 guru profesional tingkat dasar hingga menengah di Ghana (Asamani et al., 2015) menunjukkan bahwa kepuasan orientasi karir pada guru di Ghana secara signifikan mempengaruhi kepuasa hidup mereka, dimana dedikasi layanan (dimensi rasa pelayanan) menjadi prediktor yang paling signifikan bagi dalam pengalaman karir guru perempuan. Sedangkan guru laki-laki ditemukan secara signifikan lebih tinggi pada aspek tantang murni, otonomi dan kompentensi manajerial.

Erikson berpendapat (Yurike, 2014) bahwa perempuan terkadang dianggap sebagai pekerja yang "kebetulan" memasuki lapangan kerja sebelum akhirnya mereka menikah dan mempunyai anak. Hal ini senada dengan Rodrigues et al. (2013) yang menyebutkan bahwa perempuan lebih sering merubah orientasi karirnya setelah menikah atau memiliki anak.

Hasil penelitian ini menunjukkan bahwa terdapat perbedaan orientasi karir pada guru laki-laki dan perempuan pada dimensi jangkar karir kompetensi manajerial hal ini dikarenakan bagi masayarakat Indonesia, masih memandang bahwa laki-laki dianggap harus memiliki jiwa kepemimpinan dan menyukai tantangan, sedangkan stigma pada pekerja perempuan lebih berorientasi pada keluarga dan tidak menyukai konflik (Widodo et al., 2020). Selain itu masyarakat juga menganggap bahwa perempuan cocok menjadi seorang guru karena memiliki naluri keibuan, sebagaimana Data Statistik Kemdikbud Tahun 2015-2016 menunjukkan bahwa guru perempuan mendominasi sebesar $63 \%$ atau perbandingan 63:37 dengan jumlah guru laki-laki (No, 2016).

Penelitian Wang et al. (2019) terhadap dokter di Shanghai-China juga menunjukkan bahwa dokter umum laki-laki lebih tinggi dari dokter perempuan pada dimensi jangkar karir kompetensi manajerial. Begitu pula hasil penelitian Susanti (2014) juga menemukan bahwa terdapat perbedaan signifikan antara laki-laki dan perempuan pada jangkar karir kemanan kerja, rasa pelayanan, tantangan murni dan

Dipublikasikan Oleh :

UPT Publikasi dan Pengelolaan Jurnal

Universitas Islam Kalimantan Muhammad Arsyad Al-Banjari Banjarmasin 


\section{Khaeriah $^{1}$, Dede Rahmat Hidayat ${ }^{2}$, Herdi $^{3}$ \\ Jurnal Mahasiswa BK An-Nur : Berbeda, Bermakna, Mulia \\ Volume 7 Nomer 3 Tahun 2021 \\ Tersedia Online: https://ojs.uniska-bjm.ac.id/index.php/AN-NUR \\ p-ISSN. 2460-9722 | e-ISSN. 2622-8297}

kompetensi manajerial generasi $\mathrm{X}$ dan $\mathrm{Y}$. hal ini senada pula dengan penelitian Crook dkk dan Igbaria dkk (Igbaria \& Baroudi, 1993) yang menyebutkan bahwa jenis kelamin mempengaruhi jangkar karir seseorang. Maka dapat disimpulkan bahwa analisis berdasarkan variabel jender ikut berperan dalam hasil penelitian ini.

\section{Orientasi Karir Guru Berdasarkan Jenjang Pendidikan \\ Pendidikan sebagai salah satu kualifikasi} akademik untuk menjadi seorang guru telah ditentukan pemerintah yaitu minimal harus lulusan sarjana strata 1 (S1). Hasil penelitian Mukti (2017) menemukan bahwa terdapat hubungan yang kuat antara kualifikasi pendidikan dan pengembangan karir terhadap prodiktivitas kerja guru. Menurut Darwin (2002) guru dikatakan profesional dapat dilihat dari dua perspektif yaitu latar belakang pendidikan dan penguasaan guru tersebut terhadap tugasnya.

Umumnya, semakin tinggi tingkat pendidikan guru, makan akan semakin menambah pengetahuan dan keterampilan guru, sehingga ia bisa mengembangkan pula jenjang karir yang lebih tinggi yang tentu akan mempengaruhi orientasi karirnya karena pengembangan pengembangan profesi dan karir guru telah tertuang dalam Undang_Undang No. 14 tahun 2015 tentang guru dan dosen. RIvai dan Jauvani (Irmayani, 2018) menyebutkan bahwa salah satu faktor yang mempengaruhi pengembangan karir seseorang adalah pendidikan.

Dalam penelitian ini tidak ditemukan adanya perbedaan orientasi karir pada guru MAN IC baik yang memiliki jenajang pendidikan S1, S2 maupun S3. Hal ini berbeda dengan penelitian Dewi, \& Bagia (2016) yang menyatakan bahwa terdapat pengaruh positif antara tingkat pendidikan dengan pengembangan karir dan kinerja seseorang. Begitu juga berbeda dengan hasil penelitian Wang et al. (2019) yang menunjukkan bahwa skor dokter yagn memiliki latar belakang pendidikan minimak bachelor lebih tinggi skornya dalam jangkar karir kompetensi manajerial dan otonomi dari pada dokter yang memiliki latar belakang pendidikan dibawahnya.

Penulis menganalisa adanya perbedaan ini dikarenakan adanya program diseminasi yang dilakukan oleh Direktorak Jenderal Guru dan Teanga Kependidikan (Dirjen GTK) Madrasah kepada guruguru MAN IC di seluruh Indonesia. Program diseminasi ini memberikan tugas, tanggunjawab, wewenang dan kesempatan yagn sama bagi semua guru MAN IC, baik junior maupun senior, baik yang memiliki pendidikan S1, S2 maupun S3.

\section{Orientasi Karir Guru Berdarkan Asal Daerah (Letak Geografis)}

Asal daerah mempengaruhi orientasi karir guru, baik yang berkaitan dengan budaya daerah maupun faktor geografis daerah tersebut. Pada umumnya guru-guru yang lahir dari perkotaan di Pulau Jawa akan jarang mau ditempatkan untuk mengajar di daerah terpencil apalagi di luar Pulau Jawa. Sehingga terjadilah kurang meratanya jumlah guru di berbagai daerah, hal ini membuat pemerintah harus membuat program SM3T yaitu program pengabdian sarjana mendidik di daerah terluar, terdepan dan tertinggal agar memenuhi kebutuhan tenaga pendidik atau guru diberbagai daerah. Bahkan Subandrijo (2001) menyarankan model pembinaan guru di daerah terpencil agar mereka tetap semangat untuk mendidik. Hal ini menujukkan bahwa letak geografis wilayah mempengaruhi orientasi karir pada guru yaitu termasuk pada dimensi jangkar karir kemanan geografis.

Selain faktor geografis, budaya juga sering mempengaruhi pembentukan orientasi karir seseorang. Misalnya saja beberapa stereotip budaya di Indoensia turun menurun meyakini bahwa orang Minang terkenal memiliki jiwa daganb dan rantau (Anggun, 2016), atau orang Batak terkenal sebagai gudangnya pengacara (Editor, 2021), atau orang Jawa yang dikenal tekun, rajin dalam bekerja (Darmoko, 2017) dan stereotip budaya daerah lainnya. Belum lagi faktor budaya luar yang mempengaruhi masyarakat, seringkali generasi muda lebih menyukai budaya luar dan budaya lokal hanya digemari oleh minoritas generasi tua (Pranoto, 2005).

Bagi masyarakat Indonesia, pekerjaan aman seperti Pegawai Negeri Sipil (PNS) tetap menjadi profesi primadona dimasyarakat hal ini karena adanya jaminan uang pensiuan, tunjangan dan jenjang karir yang jelas, hal ini tentu berkaitan dengan dimensi keamanan kerja dan kompetensi manajerial (Widodo et al., 2020). Kebtuhan akan kemanan dalam kerja juga berkaitan dengan Hirarki kebutuhan Maslow (basic need: fisiologis, kemananan sosial, harga diri, aktualisasi diri) sehingga orang tidak akan bertahan atau nyaman bekerja jika kebutuhan rasa aman ini tidak terpenuhi (Wang et al., 2019; Bravo et al., 2017).

Hasil penelitian ini menunjukkan bahwa terdapat perbedaan orientasi karir pada guru MAN IC berdasarkan latar belakang asal daerah (geografis)

Dipublikasikan Oleh : 


\section{Khaeriah $^{1}$, Dede Rahmat Hidayat ${ }^{2}$, Herdi $^{3}$ \\ Jurnal Mahasiswa BK An-Nur : Berbeda, Bermakna, Mulia \\ Volume 7 Nomer 3 Tahun 2021 \\ Tersedia Online: https://ojs.uniska-bjm.ac.id/index.php/AN-NUR \\ p-ISSN. 2460-9722 | e-ISSN. 2622-8297}

pada dimensi jangkar karir keamanan kerja dan skor dengan rata-rata tertinggi yaitu guru yang berasal dari pulau Jawa. Keamananan kerja merupakan dimensi jangkar karir terkait nilai, kebutuhan, motif yang berkaitan dengan loyalitas lembaga, keamanan finansial, dan jejang karir jangka panjang. Penulis menganalisa pertama, bahwa MAN IC secara historis dulunya adalah sekolah swasta (MAN ICS yang berada di pulau Jawa), awalnya didirikan oleh BPPT yang sangat memperhatikan kesejahteraan gurunya, MAN IC sendiri dari awal didirikan memang menjadi salah satu pilot project BPPT untuk membangun sekolah unggulan dengan mengedepankan keseimbangan ilmu pengetahuan dan imtaq. MAN IC dikonsep untuk menjadi salah satu sekolah unggulan yang menciptakan generasi berprestasi namun tetap religius, dengan adanya tuntutan lembaga untuk menjaga prestasi dan kualitas MAN IC serta sedari awal berdiri memang kesejahteraan guru sangat diperhatikan maka wajarlah jika guru-gurunya memiliki orientasi yang tinggi dalam jangkar karir kemanan kerja. Kedua, adanya perbedaan ini kemungkinan disebabkan karena MAN ICS yang berada di pulau Jawa menjadi magnet school bagi Madrasah IC lainnya maupun Madrasah sekitarnya. MAN ICS ini seringkali menjadi tempat pembinaan siswa untuk mengikuti lomba, jumlah siswa ICS sendiri juga termasuk yang terbanyak dibandingkan kuota jumlah siswa di IC lainnya, sehingga dengan

\section{PENUTUP}

Berdasarkan tujuan dari penelitian yaitu untuk mengeksplorasi orientasi karir pada guru MAN IC berdasarkan latar belakang gender, jenjang pendidikan dan asal daerah (letak geografis). Hasil penelitian menunjukkan bahwa dari sembilan dimensi jangkar karir, tidak terdapat perbedaan orientasi karir pada guru MAN IC berdasarkan latar belakang gender pada tujuh dimensi jangkar karir, kecuali pada dimensi kompetensi manajerial.

Dari sembilan dimensi jangkar karir tidak terdapat perbedaan signifikan orientasi karir pada guru MAN IC berdasarkan jenjang pendidikan S1, S2 maupun S3. Dari sembilan dimensi jangkar karir, tidak terdapat perbedaan signifikan orientasi karir pada guru MAN IC berdasarkan latar belakang asal daerah (geografis) pada tujuh dimensi jangkar karir, kecuali pada dimensi kompetensi manajerial dan keamanan kerja.

Rekomendasi penelitian ini diantaranya yaitu bagi guru maupun lembaga MAN IC agar menjadi bahan evaluasi untuk memperhatikan orientasi adanya siswa yang lebih banyak, kebutuhan untuk melatih siswa lebih banyak karena banyak juga kejuaraan atau lomba yang sering diikuti, maka ICS mendapatkan anggaran DIPA yang paling besar pula dibandingkan dengan IC di daerah lainnya.

Sebagaimana hasil penelitian Arifianto (2010) menyebutkan bahwa pendidikan di perkotaan di pulau Jawa memiliki kualitas yang lebih baik jika dibandingkan dengan pendidikan di luar Pulau Jawa. Selain itu biaya hidup di perkotaan di pulau Jawa pun tentu lebih tinggi dibandingkan di daerah lain sehingga wajar guru-gurunya memiliki skor tinggi dalam dimensi jangkar karir keamanan kerja.

Pada dimensi jangkar karir kompetensi manajerial, justru guru MAN IC yang berasal dari pulau Jawa memiliki skor terendah. Penulis menganalisa hal ini karena guru-guru MAN IC di pulau Jawa (terutama MAN ICS karena jumlah responden paling banyak) merupakan guru-guru senior yang merintis karir bersama. Orientasi utama mereka adalah mendidik dan membimbing siswa untuk mencapai prestasi yang tinggi, dan mereka tidak terlalu mengejar jabatan karena kebahagiaan bekerja sebagai guru ketika melihat siswanya bisa sukses berprestasi dibanding mengejar jabatan.

karirnya. Sedangkan bagi peneliti selanjutnya diharapkan dapat menambah variabel penelitian orientasi karir pada guru dengan menambah variabel kepuasan kerja, kepuasan organisasi dan kinerja guru.

\section{REFERENSI}

Akmal, S. Z., \& Arlinkasari, F. (2017). Career Orientation Scale: Validity and Reliability Test with Confirmatory Factor Analysi. International Conference on Education and Social Science, February 2018.

Anggun, T. G. (2016). Sebab Orang Minang Sukses di Rantau.

https://sumbarprov.go.id/home/news/9319sebab-orang-minang-sukses-di-rantau.html

Arifianto, E. (2010). Mengukur Kinerja Kota-Kota Di Indonesia Dengan Pendekatan City Development Index (CDI): Kajian Studi Pada 32 Kota Di Pulau Jawa Tahun 2008 [Universitas Indonesia]. http://lib.ui.ac.id/file?file=digital/131609-T 27560-Mengukur kinerja-Metodologi.pdf

Asamani, L., Cobbold, C., \& Dai-Kosi, A. D. (2015).

Dipublikasikan Oleh : 
Khaeriah $^{1}$, Dede Rahmat Hidayat ${ }^{2}$, Herdi $^{3}$

Jurnal Mahasiswa BK An-Nur : Berbeda, Bermakna, Mulia

Volume 7 Nomer 3 Tahun 2021

Tersedia Online: https://ojs.uniska-bjm.ac.id/index.php/AN-NUR

p-ISSN. 2460-9722 | e-ISSN. 2622-8297

Career orientations as antecedent of perceived life satisfaction among Ghanaian teachers. Public Policy and Administration Research, 5(4), 84-94. researchgate.net

Asnita Putri Dewi, dan R. (2020). (Jurnal Manajemen, Kepemimpinan, dan Supervisi Pendidikan) P-ISSN: 2548-7094 E-ISSN 26148021. 5(1).

Bravo, J., Seibert, S. E., Kraimer, M. L., Wayne, S. J., \& Liden, R. C. (2017). Measuring Career Orientations in the Era of the Boundaryless Career. Journal of Career Assessment, 25(3), 502-525. https://doi.org/10.1177/1069072715616107

Chandra, Y. (2017). Tingkat Aspirasi Karir Siswa Di Tinjau Dari Jenis Kelamin. Jurnal Edukasi: Jurnal Bimbingan Konseling, 3(2), 199. https://doi.org/10.22373/je.v3i2.3096

Coetzee, M., Bergh, Z., \& Schreuder, D. (2010). The influence of career orientations on subjective work experiences. SA Journal of Human Resource Management, 8(1), 1-13. https://doi.org/10.4102/sajhrm.v8i1.279

Darmoko. (2017). Budaya Jawa Dalam Diaspora: Tinjauan Pada Masyarakat Jawa di Suriname. $1-19$.

https://journal.uny.ac.id/index.php/ikadbudi/arti cle/download/12307/8764

Darwin, S. (2002). Inovasi Pendidikan dalam Upaya Peningkatan Profesionalisme Tenaga Kependidikan. Pustaka Setia.

Disas, E. P. (2017). Analisis Kebijakan Pendidikan Mengenai Pengembangan Dan Peningkatan Profesi Guru. Jurnal Penelitian Pendidikan, 17(2). https://doi.org/10.17509/jpp.v17i2.8251

Editor. (2021). Kenapa Orang Batak Terkenal dengan Profesi Pengacara_.

Igbaria, M., \& Baroudi, J. J. (1993). Linked references are available on JSTOR for this article: A Short-Form Measure of Career Orientations: A Psychometric Evaluation. Journal of Management Information Systems, 10(2), 131-154.

Igbaria, M., Greenhaus, J. H., \& Parasuraman, S. (1991). Career orientations of MIS employees: An empirical analysis. MIS Quarterly: Management Information Systems, 15(2), 151169. https://doi.org/10.2307/249376

Irmayani, N. A. (2018). Pengaruh Pendidikan Dan Pengembangan Karir Terhadap Kinerja Pegawai Pada Dinas Pemuda Dan Olahraga Provinsi Jawa Barat (Issue 21). Universitas
Pasundan.

Leong, F. T. L., Rosenberg, S. D., \& Chong, S. H. (2014). A Psychometric Evaluation of Schein's (1985) Career Orientations Inventory. Journal of Career Assessment, 22(3), 524-538. https://doi.org/10.1177/1069072713498685

Mukti, S. (2017). Pengaruh Tingkat Pendidikan dan Pengembangan Karir Terhadap Kinerja Karyawan. Jurnal Manajemen Indonesia, 4(1), 81-90.

Mundiri, A., \& Bariroh, A. (2019). Amplifikasi Profesi Guru Dalam Proses Pendidikan Transformatif Perspektif Al-Ghazali. Jurnal Ilmiah Islam Futura, 18(1), 159. https://doi.org/10.22373/jiif.v18i1.3288

Mustofa, -. (2012). Upaya Pengembangan Profesionalisme Guru di Indonesia. Jurnal Ekonomi Dan Pendidikan, 4(1), 76-88. https://doi.org/10.21831/jep.v4i1.619

No. (2016). 63\% Guru adalah Perempuan Benarkah Profesi Ini Lebih Cocok Bagi Kaum Hawa? (Https://Www.Panduanmengajar.Com/2016/10/ Guru-Perempuan.Html.

Pranoto, S. W. (2005). Budaya Daerah Dalam Era Desentralisasi. Humaniora, 17(3), 236-242.

Rodrigues, R., Guest, D., \& Budjanovcanin, A. (2013). From anchors to orientations: Towards a contemporary theory of career preferences. Journal of Vocational Behavior, 83(2), 142152. https://doi.org/10.1016/j.jvb.2013.04.002

S. Dewi, I.W. Bagia, G. P. A. . S. (2016). Pengaruh Tingkat Pendidikan dan Pengembangan Karir Terhadap Kinerja Karyawan. Jurnal Dinamika DotCom, 4(1), 1-8. http://dx.doi.org/10.35137/jmbk.v9i1.523

Saputri, Y. Y., \& Yusuf, A. (2016). Orientasi karir pada peserta didik di sma negeri 1 sungai raya. Jurnal Penelitian Bimbingan Dan Konseling, 1(1), 1-9.

Schein, E. H. (1990). Career anchors and job/role planning: The links between career pathing and career development. Career Development: Theory and Practice, September, 207-218.

Subandrijo. (2001). Pembinaan Guru di Daerah Terpencil. Jurnal Ilmu Pendidikan, Jilid 8 No.

Susanti, R. R. (2014). Abstrak. Differences of Career Anchor in Generation $X$ and Generation $Y$ Employee. Abstract. Pendahuluan - PDF Free Download.pdf. Fakultas Psikologi, Universitas Indonesia.

Trisnowati, E. (2016). Program Bimbingan Karir untuk Meningkatkan Orientasi Karir Remaja.

Dipublikasikan Oleh :

UPT Publikasi dan Pengelolaan Jurnal

Universitas Islam Kalimantan Muhammad Arsyad Al-Banjari Banjarmasin 
Khaeriah $^{1}$, Dede Rahmat Hidayat ${ }^{2}$, Herdi $^{3}$

Jurnal Mahasiswa BK An-Nur : Berbeda, Bermakna, Mulia

Volume 7 Nomer 3 Tahun 2021

Tersedia Online: https://ojs.uniska-bjm.ac.id/index.php/AN-NUR

p-ISSN. 2460-9722 | e-ISSN. 2622-8297

SOSIAL HORIZON: Jurnal Pendidikan Sosial, $3(1), 41-53$.

Utami, S. (2019). Meningkatkan Mutu Pendidikan Indonesia Melalui Peningkatan. Prosiding Seminar Nasional Pendidikan FKIP, 2(1), 518527.

Vargas, R. C., \& Teixeira, A. (2018). Satisfaction at IFES: An analysis through career anchors. Revista de Administracao Mackenzie, 19(3). https://doi.org/10.1590/1678-

6971/eRAMG180101

Vito, B., \& Krisnani, H. (2015). Kesenjangan Pendidikan Desa Dan Kota. Prosiding Penelitian Dan Pengabdian Kepada Masyarakat, 2(2), 247-251. https://doi.org/10.24198/jppm.v2i2.13533

Wang, J., Zhao, Q., Liu, T., An, M., \& Pan, Z. (2019). Career orientation and its impact factors of general practitioners in Shanghai, China: A cross-sectional study. BMJ Open, 9(3), 1-9. https://doi.org/10.1136/bmjopen-2018-021980

Widodo, S., Meiliani, M., \& Muchiri, M. K. (2020). Investigating Factor Structures Underlying the Construct of Career Anchor Inventory in the Indonesian Context. Proceeding of the 4th International Conference on Business, Management \& Edonomics, 1-14. https://www.dpublication.com/proceeding/4thicbmeconf/\#Table-of-Contents

Yuksel-Sahin, F., \& Hotaman, D. (2009). Vocational guidance aid in the orientation to teaching profession and teacher education. European Journal of Social Sciences, 10(1), 25-35.

Yurike. (2014). Perbedaan Orientasi Karir..., Yurike Budiargo, Fakultas Psikologi UMP, 2014. 926.

Dipublikasikan Oleh :

UPT Publikasi dan Pengelolaan Jurnal

Universitas Islam Kalimantan Muhammad Arsyad Al-Banjari Banjarmasin 